\title{
EFL Vocabulary Learning Strategies Among High School Students
}

\author{
Biljana Radić-Bojanić1 \\ Department of English Studies, Faculty of Philosophy, \\ University of Novi Sad, Novi Sad, Serbia
}

\begin{abstract}
The paper examines how frequently high school students use EFL vocabulary learning strategies and whether contextual educational factors have any influence on strategy selection. The theoretical part discusses the importance of language learning strategies, which can facilitate the internalization, storage, retrieval, or use of the new language, factors that affect their usage and selection (e.g. nature of the task, students' motivation, foreign language proficiency, teacher's expectations, students' learning styles, students' gender), as well as the process of vocabulary acquisition. The empirical part presents the results of the analysis of a survey conducted among students from two high schools in Serbia, a vocational school and a grammar school. The aim of the research is to determine how frequently students use vocabulary learning strategies and if there are any statistically significant differences in strategy use between students from the two schools which are the consequence of different subjects and learning objectives. The results show that the majority of vocabulary learning strategies have medium use among high school students (seven out of nine memory strategies, seven out of nine cognitive strategies and two out of four compensatory strategies) and that there are certain inter-group differences (whereas students from the medical high school use memory strategies more frequently, students from the grammar school report higher use of cognitive and compensatory strategies). The results indicate that there are important cross-curricular links which point to the transfer of learning strategies from content subjects to English language classes.
\end{abstract}

Keywords: vocabulary learning, language learning strategies, high school, students, EFL, questionnaire.

\section{Introduction}

Within the Communicative Approach to foreign language teaching vocabulary has great importance as it has been established that a successful use of the foreign language implies a vast vocabulary both for receptive and productive skills. Therefore,

1 radic.bojanic@ff.uns.ac.rs 
it is important to constantly increase one's vocabulary in order to communicate successfully and this can be done in a variety of ways. The many approaches to vocabulary acquisition depend on the learners' age, level, purpose of foreign language learning, etc. Regardless of all these factors, if vocabulary acquisition is to be successful and permanent, this process is best regulated by language learning strategies, which are effective, purposeful and directed attempts of the learner to consciously apply different techniques, methods and approaches in order to acquire the vocabulary items of the foreign language. In this paper we use the quantitative approach to examine how frequently high school students in two secondary schools in Novi Sad, Serbia, use different strategies in the acquisition of vocabulary of English as a foreign language and we try to ascertain possible differences among groups of strategies as well as differences between two groups of high school students (grammar school vs. medical high school) in order to discover if the contextual educational factors play a role in the selection of strategies and how.

\section{Theoretical background}

Language learning strategies (henceforth LLS) have been one of the pivotal concepts in the field of foreign language learning over the last few decades and have merited a vast body of research. Defined as "processes, techniques, approaches and actions that students take to facilitate the learning and recall of both linguistic and content areas of information" (Chamot, 1987, p. 71), LLS have been researched from a number of different angles, always with the idea to find the most adequate combinations for various groups of students. What researchers such as Rubin (Rubin, 1975), Wenden (Wenden, 1987), O'Malley and Chamot (O'Malley \& Chamot 1990), Oxford (Oxford, 1990), Ellis (Ellis, 1994) and Williams and Burden (Williams \& Burden, 1997) have established is that LLS are learning processes consciously selected by the learner which can facilitate the internalization, storage, retrieval, or use of the new language (Oxford, 1990, p. 4; Cohen, 1998, p. 5). LLS help learners in a number of ways because students are able to "identify the material that needs to be learned" (Chen, 2016, p. 4) (e.g. to make a distinction between familiar and new words), "distinguish it from other material if need be" (Chen, 2016, p. 4) (e.g. decide if a new word should be learnt or not at that point in the learning process), group "it for easier learning (e.g., grouping vocabulary by category into nouns, verbs, adjectives, adverbs etc.), have repeated contact with the material (e.g., through classroom tasks or homework assignments), and formally commit the material to memory when it does not seem to be acquired naturally (whether through rote memory techniques such as repetition, the use of mnemonics, or some other memory technique)" (Chen, 2016, p. 4).

Having in mind many factors present in the process of foreign language learning, it is inevitable that some of them have a direct influence on the selection and presence of LLS. For example, the nature of the task determines the scope and possible combination of LLS (Oxford, 1990, p. 13), students' motivation influences the number and appropriateness of LLS (Cohen, 2003) and foreign language proficiency also has a similar effect on LLS (Pavičić Takač, 2008, p. 55; Crnogorac Stanišljević, 2018, p. 259). Furthermore, the 
teacher's expectations can play an important role in the selection of LLS as the teaching paradigm (e.g. the communicative approach vs. the grammar translation approach) will put some strategies in the foreground and others will be incompatible with the methods used in the classroom (Oxford, 1990, p. 13). Brown (Brown, 2000, pp. 11-12) also emphasizes that the student's learning style has a powerful effect on the choice of LLS, so for example, students with the dominant analytical learning style will prefer cognitive strategies of analysis, deductive reasoning or translation (also see Komaromi, 2012). Finally, Catalan (Catalan, 2003) and Bikicki (Bikicki, 2012) stipulate that the students' gender is also significant where LLS are concerned claiming that female students use a wider range of strategies in comparison to male students. However, so far there have been no studies concerning LLS that have investigated the interplay of contextual educational factors such as the type of school or studies attended by students, so this paper will attempt to find out if such a factor could play a role in the selection of LLS, more precisely vocabulary learning strategies.

As previously said, vocabulary has a great importance in foreign language learning (Sadoski, 2005, p. 221), especially in the communicative approach to foreign language teaching, as it was proven that successful communication in the foreign language primarily relies on a vast vocabulary (Nation, 2001). In the process of vocabulary acquisition the role of LLS is crucial because they first increase the number of lexical items that students commit to long-term memory (Nunan, 1995, p. 133) and also because they help students become autonomous in the process of language learning (Radić-Bojanić, 2013). This is particularly important because students will eventually use the foreign language independently, outside of the classroom and without any help from the teacher or dictionary, so they ought to decrease their dependence on external help and develop strategies which will help them to cope on their own (Oxford, 1990, p. 10). In other words, vocabulary knowledge is not only part of students' linguistic competence, but also part of their strategic competence because knowing which LLS to use and when is of crucial importance for both successful learning and successful communication (Read, 2000, pp. 17-21). As Benson and Voller have demonstrated, autonomy in the process of learning the foreign language can be enhanced if students are allowed to identify their own strategies and if they are aware of the mental processes and techniques employed (Benson \& Voller, 2014).

LLS themselves are classified by various authors in a number of ways, but the most influential and most widely used taxonomy is the one proposed by Oxford (Oxford, 1990), where she divides all strategies into direct (directly involve the target language) and indirect strategies. Since the latter group of strategies only tackles the factors that surround the process of learning (metacognition, social contacts and students' affective states), the research in this paper focuses on the former group of strategies, which are further divided into memory strategies (creating mental linkages, applying images and sounds, reviewing well, employing action), cognitive strategies (practicing, receiving and sending messages, analyzing and reasoning, creating structure for input and output) and compensatory strategies (guessing intelligently, overcoming limitations in speaking and writing), which are intersected with various contexts of vocabulary acquisition, as explained further in the paper. 


\section{Research methodology}

As previously stated, in the paper we examine EFL vocabulary learning strategies used by high school students in two high schools in Serbia. The research was conducted in high schools in Novi Sad in the period September-November 2019. The sample consists of 217 high school students from the fourth grade, $N=131$ from a grammar school (a general, comprehensive high school) and $N=86$ from a medical high school (a vocational, professional high school). More precisely, the first subsample included four classes comprising 32-34 students, while the second subsample included three classes comprising 28-29 students. Where the age of the students is concerned, all of them were 18 years old and, being of age, were able to sign a research consent themselves. In this research we did not use gender as a relevant factor, so this data is not included in the sample description or the analysis. As this was the group of informants we had access to, it can be said that this was a convenience sample.

The instrument used in the research is a slightly modified version of Oxford's (Ox-

ford, 1990) Strategy Inventory for Language Learning (SILL). Namely, at the beginning of the questionnaire we added a group of questions intended to collect general information about the informants (age, class, school), which was followed by 22 questions from the SILL that cover direct learning strategies referring to EFL vocabulary acquisition. The students were supposed to assess these 22 questions on a 5-point Lickert scale ranging from 'never true of me' to 'always true of me'.

After the data was collected, it was coded and analyzed in SPSS 20.0. We conducted the following statistical tests: Mean, Standard Deviation, and independent samples $t$-test for differences between the two subsamples.

In the research we start from two hypotheses: 1. students' use of vocabulary learning strategies is low; 2 . there is a difference in strategy use between the two schools (cf. Pašalić, 2013).

\section{Research results}

In order to test the first hypothesis regarding the frequency of vocabulary acquisition strategies among high schools students in Serbia, we calculated the Mean and Standard Deviation for each strategy in all three groups. Relying on Oxford (Oxford, 1990), we determined that the low frequency ranged from 1.0 to 2.4 , the medium frequency ranged from 2.5 to 3.4, and that the high frequency ranged from 3.5 to 5 .

Table 1 shows the repertoire of memory strategies and their mean frequency along with standard deviation. Seven out of nine strategies have medium use, while only two strategies, the use of flashcards and the Total Physical Approach, have a low use apparently because they are not typical of high school students. 
Table 1

Average frequency of use of memory strategies

\begin{tabular}{lcc}
\hline Memory strategies & $M$ & $S D$ \\
\hline $\begin{array}{l}\text { I think of relationships between what I already know and new things I learn in } \\
\text { English. }\end{array}$ & 2.99 & 1.386 \\
I use new English words in a sentence so I can remember them. & 2.86 & 1.172 \\
$\begin{array}{l}\text { I connect the sound of a new English word and an image or picture of the word to } \\
\text { help me remember the word. }\end{array}$ & 2.93 & 1.3777 \\
I remember a new English word by making a mental picture of a situation in which & 3.11 & 1.365 \\
the word might be used. & 2.41 & 1.378 \\
I use rhymes to remember new English words. & 1.72 & 1.185 \\
I use flashcards to remember new English words. & 1.69 & 1.218 \\
I physically act out new English words. & 2.57 & 1.289 \\
I review English lessons often. & 2.70 & 1.482 \\
\hline $\begin{array}{l}\text { I remember new English words or phrases by remembering their location on the } \\
\text { page, on the board, or on a street sign. }\end{array}$ & & \\
\hline
\end{tabular}

Table 2 presents all cognitive strategies and their mean frequency. Just like with the previous group, seven out of nine strategies have medium use, but two remaining strategies stand out. On the one hand, the strategy with low use (writing notes, messages, letters, or reports by dividing it into parts) is the result of the fact that students rarely write in English, let alone notes, letters or reports. On the other hand, the strategy with high use (watching English language TV shows spoken in English or going to movies spoken in English) reflects students' habits in spending their free time, as well as the fact that none of the series and films in Serbia are dubbed, which provides direct and authentic linguistic input and obviously has a positive effect on EFL vocabulary acquisition.

Table 2

Average frequency of cognitive strategies

\begin{tabular}{lcc}
\hline Cognitive strategies & $M$ & SD \\
\hline I say or write new English words several times. & 2.83 & 1.415 \\
I use the English words I know in different ways. & 3.24 & 1.353 \\
I start conversations in English. & 2.78 & 1.402 \\
I watch English language TV shows spoken in English or go to movies spoken in & 4.01 & 1.130 \\
English. & 2.63 & 1.425 \\
I read for pleasure in English. & 2.37 & 1.341 \\
I write notes, messages, letters, or reports by dividing it into parts that I understand. & 2.59 & 1.303 \\
I look for words in my own language that are similar to new words in English. & 2.61 & 1.370 \\
I find the meaning of an English word by dividing it into parts that I understand. & 3.31 & 1.244 \\
\hline I try not to translate word-for-word. & & \\
\hline
\end{tabular}


Finally, the average frequency of compensatory strategies in Table 3 shows that two out of four strategies have medium use, while one strategy (making up new words) has low use. We can conclude that students obviously do not feel comfortable in the creative use of language, but the use of synonyms has high frequency, which testifies to a certain richness of vocabulary.

Table 3

Average frequency of compensatory strategies

\begin{tabular}{lcc}
\hline Compensatory strategies & $M$ & SD \\
\hline To understand unfamiliar English words, I make guesses. & 2.98 & 1.182 \\
When I can't think of a word during a conversation in English, I use gestures. & 3.07 & 1.381 \\
I make up new words if I do not know the right ones in English. & 2.17 & 1.372 \\
If I can't think of an English word, I use a word or phrase that means the same thing. & 3.56 & 1.359 \\
\hline
\end{tabular}

As far as inter-group differences are concerned, in the group of memory strategies only two out of nine strategies show a higher value for students from grammar school (I think of relationships between what I already know and new things I learn in English; I connect the sound of a new English word and an image or picture of the word to help me remember the word), while in all other cases students from the medical high school have reported higher frequency of use of the strategies in question. One possible explanation is that the students from the medical high school transfer the strategies they use for memorizing other subjects from the medical field to vocabulary learning in EFL, but it is also possible that they transfer the strategies for learning Latin to vocabulary learning in EFL because they have to memorize by heart Latin terminology and various proverbs.

In the case of cognitive strategies, inter-group differences show the opposite tendency. Namely, seven out of nine cognitive strategies show a higher value for students from the grammar school (I say or write new English words several times; I use the English words I know in different ways; I watch English language TV shows spoken in English or go to movies spoken in English; I read for pleasure in English; I look for words in my own language that are similar to new words in English; I find the meaning of an English word by dividing it into parts that I understand; I try not to translate word-for-word). This can be explained by the fact that these strategies show a wider scope of mental manipulation of linguistic material and some of them employ higher order thinking skills, which essentially reflects the approach to a wide variety of subjects that students have in the grammar school, where more than rote learning is required.

Finally, three out of four compensatory strategies again show a higher value for students from grammar school (To understand unfamiliar English words, I make guesses; When I can't think of a word during a conversation in English, I use gestures; If I can't think of an English word, I use a word or phrase that means the same thing). These strategies show resourcefulness in foreign language learning and the students' ability to cope with problems and find ways to get around them, which is, again, more typical of students in the grammar school. 
In order to see which strategies show statistically significant differences in the frequency of use, we conducted an independent samples $t$-test (Table 4) and found statistically significant differences in six strategies. In all cases but the last one students from the medical high school reported higher values: the first four strategies belong to memory strategies, where medical high students scored consistently higher than grammar school students, and the last two are compensatory strategies. In general, the results of the t-test are consistent with the descriptive statistics shown in previous tables.

Table 4

Independent samplest-test for inter-group differences

\begin{tabular}{lcc}
\hline Items & $t$ & $p$ \\
\hline I use rhymes to remember new English words. & 2.676 & .008 \\
I use flashcards to remember new English words. & 4.103 & .000 \\
I physically act out new English words. & 2.846 & .005 \\
I remember new English words or phrases by remembering their location on the & 2.062 & .041 \\
page, on the board, or on a street sign. & 2.829 & .005 \\
I make up new words if I do not know the right ones in English. & -2.582 & .011 \\
\hline If I can't think of an English word, I use a word or phrase that means the same thing.
\end{tabular}

\section{Discussion}

On the basis of the results presented in the first part of the previous section we can reject the first hypothesis. Namely, the majority of strategies (16 out of 22) have medium use, two have high use and four have low use. Since the questionnaire relies on self-report, the accuracy of reported degrees of use could be somewhat problematic. As Veenman states, "learners may not be fully aware of ongoing processes, which may affect the verbalization of these processes in self-reports" (Veenman, 2011, p. 205), which means that learners may become aware of their usually automated performance only when it is verbalized in the questionnaire and can sometimes even report a higher degree of use than in reality exists. That is why we should be cautious with the results of self-report questionnaires and here we might conclude that the frequency of strategy use could be improved despite seemingly good results. Our own experience as a teacher of English suggests that in the majority of cases students are not trained in strategies, so instead, they transfer the strategies they use for other subjects to the situations when they have to learn English. This points to a great need for systematic training and awareness raising, which can be done by the teacher with the aid of course books. In other words, "the training of [these] 'strategies' would be a highly desirable activity as it would amount, in effect, to the teaching of learners ways in which they can learn better" (Dörnyei, 2005, p. 173) because most learners would benefit from an improvement of their study skills. This is in line with a wider movement in foreign language teaching that investigates the characteristics of a good language learner (cf. Griffiths, 2008) in order to impart the characteristics, approaches and techniques of successful students 
to less successful individuals, thus enhancing their chances of mastering the foreign language (Pawlak, 2011, pp. 26-27). Where LLS are concerned, students can immediately see the results of strategy training, which will consequently lead to motivated and interested participants in the learning process. As Dörnyei says, "[a]lthough the various strategy training frameworks differ in their details, they aim to achieve the same overall goals: to raise the learners' awareness about learning strategies and model strategies overtly along with the task; to encourage strategy use and give a rationale for it, to offer a wide menu of relevant strategies for learners to choose from; to offer controlled practice in the use of some strategies; and to provide some sort of a post-task analysis which allows students to reflect on their strategy use" (Dörnyei, 2005, p. 174).

The second hypothesis, on the other hand, was confirmed: students from the medical high school reported consistently higher use of memory strategies, whereas students from the grammar school reported consistently higher use of cognitive and compensatory strategies. Our deduction is that the students from the medical high school transfer learning strategies they use for memorizing other subjects from the medical field to vocabulary learning in $\mathrm{EFL}$, while the students from the grammar school use cognitive and compensatory strategies significantly more because they reflect the wider scope of subjects which are part of the grammar school curriculum and which involve higher order thinking skills, creativity, greater mental manipulation and critical thinking. In other words, as the sample includes fourth year high school students, we could say that this transfer is a consequence of the influence of the structure of the educational context and learning aims and objectives of each particular school after the students have been exposed to a particular type of input for four years. The research thus far has proven that LLS are by their nature transferable to new situations (Oxford, 1990, p. 8), but the majority of research has focused on the transfer between L1 and L2 (e.g. Chamot, 2001; Chamot, 2004). Cohen and Macaro (Cohen \& Macaro, 2007) and Marzban and Isazadeh (Marzban \& Isazadeh, 2012) have also discussed how a strategy-based approach helps L2 learners become more aware of the strategy repertoire which, if used systematically and effectively, can be easily transferred to new language learning and contexts. $\mathrm{Gu}(\mathrm{Gu}, 1996)$ found that strategies learned within a language class are less likely to transfer to other tasks, but the research presented in this paper may suggest the opposite type of transfer. As Chamot says, "[a] situation would be one in which all teachers in all subject areas teach learning strategies, as students would then be more likely to transfer strategies learned in one class to another class" and this is surely the educational context which warrants further discussion (Chamot, 2004, p. 19).

\section{Conclusion}

The research presented in this paper has raised some very important issues for a wider educational context which concerns not only foreign language teaching, but general cross-curricular links of content subjects and cognitive processes that might connect them. Namely, we established that high school students moderately use vocabulary learning strategies, which definitely shows room for improvement. This can be done through explicit strategy instruction, which focuses on the "development of students' awareness 
of the strategy utilised, teachers' modelling of strategic thinking, students' practice with new strategies, students' self-evaluation of the strategies used, and students' practice in transferring strategies to new tasks" (Chamot, 2004, p. 19). The role of English language teachers in this process is invaluable (Despotović, 2017, p. 206) because they can help students build autonomy in learning, which will bring them one step closer to being the 'good language learner' (cf. Griffiths 2008). However, the second research finding which suggests the existence of transfer of learning strategies from other subjects to English language classes opens up new avenues of research. Namely, researchers have so far focused only on strategy transfer between $L 1$ and $L 2$, but it might be necessary to take into consideration the wider educational context to explain the influence of contextual educational factors. Further avenues of research that might shed light on the interplay of different factors include an investigation of learning strategies that students use and apply in different content subjects that are general in nature (history, geography, mathematics, physics, chemistry, etc.) as well as vocational subjects that are dominant in the final years of medical high school (anatomy, physiology, microbiology, parasitology, pathology, epidemiology, hematology, etc.). In this process collaboration between teachers (cf. Glušac, 2016) is invaluable and necessary in order to achieve the best possible results for students during their entire education from the perspective of the different subjects they study.

\section{References}

Benson, P., \& Voller, P. (2014). Autonomy and independence in language learning. London: Routledge.

Bikicki, N. (2012). Razlike među polovima u upotrebi strategija za učenje vokabulara. In B. Radić-Bojanić (Ed.), Strategije i stilovi u nastavi engleskog jezika (pp. 11-25). Novi Sad: Faculty of Philosophy.

Brown, D. H. (2000). Teaching by principles: an interactive approach to language pedagogy. New York: Longman.

Catalan, R. M. J. (2003). Sex differences in L2 vocabulary learning strategies. International Journal of Applied Linguistics, 13(1), 54-77. https://doi.org/10.1111/1473-4192.00037

Chamot, A. U. (1987). The power of learning strategies. Ohio Bilingual-Multicultural Update, 4, 6-11.

Chamot, A. U. (2001). The role of learning strategies in second language acquisition. In M. B. Breen (Ed.), Learner contributions to language learning: New directions in research (pp. 25-43). Harlow: Longman.

Chamot, A. U. (2004). Issues in language learning strategy research and teaching. Electronic journal of foreign language teaching, 1(1), 14-26.

Chen, Z. J. (2016). Language learning strategies based on the educational concept of innovation and entrepreneurship. Open Access Library Journal, 3, 1-6. https://dx.doi.org/10.4236/oalib.1102780

Cohen, A. D. (1998). Strategies in learning and using a second language. Harlow: Essex, Longman.

Cohen, A. D., \& Macaro, E. (2007). Language learner strategies. Oxford: Oxford University Press.

Crnogorac Stanišljević, B. (2018). Kompenzatorne strategije u razvijanju jezičke veštine slušanja u nastavi engleskog jezika - kvalitativno istraživanje, Metodički vidici, 9(1), 249-264. https://doi. org/10.19090/mv.2018.9.249-264

Despotović, V. (2017). The teacher as the most important motivational factor in the classroom. Metodički vidici, 8(1), 195-210. https://doi.org/10.19090/mv.2017.8.195-210 
Dörnyei, Z. (2005). The psychology of the language learner: individual differences in second language acquisition. Mahwah, NJ: Lawrence Erlbaum Associates.

Ellis, R. (1994). The study of second language acquisition. Oxford: Oxford University Press.

Glušac, T. (2016). Međusobno obučavanje kolega kao oblik usavršavanja profesorâ engleskog jezika. Novi Sad: Faculty of Philosophy.

Griffiths, C. (2008). Lessons from good language learners. Cambridge: Cambridge University Press.

Gu, P.Y. (1996). Robin Hood in SLA: What has the learning strategy researcher taught us?. Asian Journal of English Language Teaching, 6(1), 1-29.

Komaromi, B. (2012). Ocena uspešnosti prilagođavanja nastave različitim stilovima učenja. In B. Radić-Bojanić (Ed.), Strategije i stilovi u nastavi engleskog jezika (pp. 103-114). Novi Sad: Faculty of Philosophy.

Marzban, A., \& Isazadeh, F. (2012). Discovery listening and explicit strategy-based-instruction models' effect on the Iranian intermediate EFL listening comprehension. Procedia - Social and Behavioural Sciences, 46, 5435-5439. https://doi.org/10.1016/j.sbspro.2012.06.453

Nation, I. S. P. (2001). Learning vocabulary in another language. Cambridge: Cambridge University Press.

Nunan, D. (1995). Language teaching methodology. Hemel Hempstead: Phoenix ELT.

O'Malley, M. J., \& Chamot, A.-U. (1990). Learning strategies in second language acquisition. Cambridge: Cambridge University Press.

Oxford, R. (1990). Language learning strategies: what every teacher should know. New York: Newbury House/Harper \& Row.

Pašalić, M. (2013). Language learning strategies and progress in EFL of students of economics and business. ESP Today, 1(1), 127-138.

Pavičić Takač, V. (2008). Vocabulary learning and foreign language acquisition. Clevedon: Multilinguial Matters.

Pawlak, M. (2011). Research in language learning strategies: taking stock and looking ahead. In J. Arabski, \& A. Wojtaszek (Eds.), Individual learner differences in SLA (pp. 17-37). Bristol: Multilingual Matters.

Radić-Bojanić, B. (2013). Strategije za razumevanje metaforičkog vokabulara. Novi Sad: Faculty of Philosophy.

Read, J. (2000). Assessing Vocabulary. Cambridge: Cambridge University Press.

Rubin, J. (1975). What the "good language learner" can teach us. TESOL Quarterly, 9(1), 41-51.

Sadoski, M. (2005). A dual coding view of vocabulary learning. Reading \& writing quarterly: overcoming learning difficulties, 21(3), 221-238.

Veenman, M. V. J. (2011). Alternative assessment of strategy use with self-report instruments: a discussion. Metacognition Learning, 6(2), 205-211. https://doi.org/10.1007/s11409-011-9080-x

Wenden, A. L. (1987). Conceptual background and utility. In A. L. Wenden, \& J. Rubin (Eds.), Learner strategies in language learning (pp. 3-13). Englewood Cliffs, NJ: Prentice-Hall.

Williams, M., \& Burden, R. L. (2001). Psychology for language teachers. Cambridge: Cambridge University Press.

Примљено: 22.02. 2021.

Коригована верзија примљена: 13. 04. 2021.

Прихваћено за штампу: 16. 04. 2021. 


\title{
Стратегије за учење вокабулара енглеског језика као страног код ученика средњих школа
}

\author{
Биљана Радић-Бојанић \\ Одсек за англистику, Филозофски факултет, \\ Универзитет у Новом Саду, Нови Сад, Србија
}

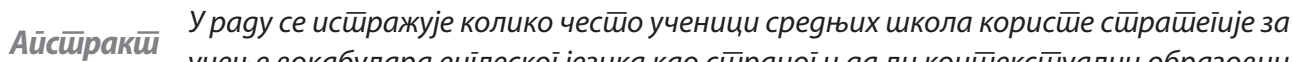

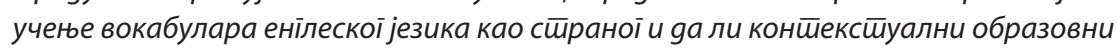

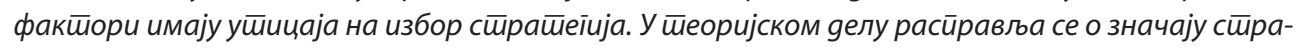

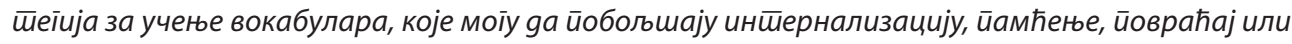

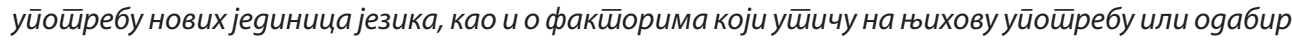

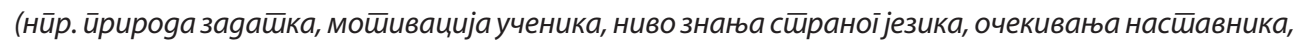
ученички сӣил учењ а, као и њихов ӣол) и йрочесу усвајања вокабулара. Емӣиријски gео раgа

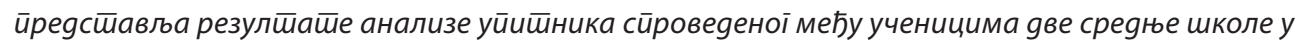
Србији - јеgне стиручне школе и јеgне іимназије. Циљ исйраживања је gа се оgреgи колико чесӣо

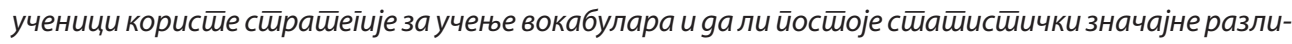
ке између ученика из gве школе, шӣо би моїла gа буgе йослеgица различишиих образовних циље-

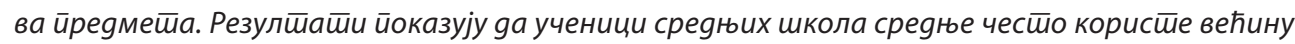

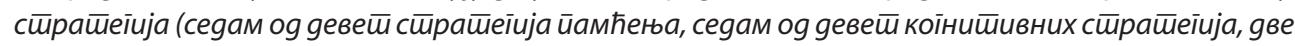

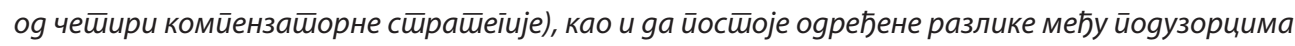

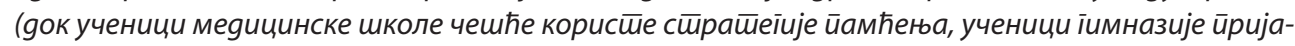

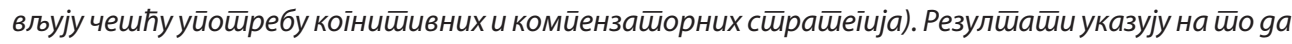

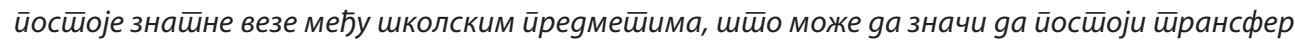
сиирайеїија за учење из gруїих йреgмейа на йреgмей енілескої језика.
\end{abstract}

Кључне речи: учење вокабулара, сишрайеїије за учење језика, среgња школа, ученици, енїлески језик као сиирани, уйийник. 


\title{
Стратегии изучения лексики английского как иностранного языка у учащихся средних школ
}

\author{
Биляна Радич-Боянич \\ Кафедра англистики, Философский факультет, \\ Нови-Садский университет, Нови-Сад, Сербия
}

\begin{abstract}
Резюме В статье исследуется, как часто старшеклассники используют стратегии для изучения лексики английского языка и влияют ли контекстные образовательные факторы на выбор стратегий. В теоретической части обсуждается важность стратегий изучения словарного запаса, которые могут улучшить усвоение, память, восстановление или использование новых языковых единии, а также факторы, влияющие на их использование или выбор (например, характер задания, мотивачия учащегося, уровень владения иностранным языком, ожидания учителя, стиль обучения учащихся, а также их пол) и процесс приобретения словарного запаса. В эмпирической части статьи представлены результаты анализа анкеты, проведенной среди учащихся двух средних школ в Сербии, одна из которых является специальной, а другая гимназией. Цель исследования - определить, как часто учащиеся используют стратегии для изучения словарного запаса и существуют ли статистически значимые различия между учащимися из двух школ, которые могут быть следствием различных учебных предметов и образовательных целей. Результаты показывают, что ученики достаточно часто используют большинство стратегий (семь из девяти стратегий памяти, семь из девяти когнитивных стратегий, две из четырех компенсаторных стратегий) и что есть некоторые различия между подвыборками (в то время какученики медицинской школы чаще используют стратегии памяти, ученики гимназии сообщают о более частом использовании когнитивных и компенсаторных стратегий). Результаты показывают, что между учебными предметами существуют существенные связи, обеспечивающие перенос стратегий обучения с других предметов на изучение английского языка.
\end{abstract}

Ключевые слова: изучение словарного запаса, стратегии изучения языка, средняя школа, ученики, английский как иностранный, анкета. 